\title{
DYNAMIC CHANGE OF INORGANIC ARSENIC AND METHYLARSENIC COMPOUNDS IN HUMAN URINE AFTER ORAL INTAKE AS ARSENIC TRIOXIDE
}

\author{
Hiroshi YAMAUCHI and Yukio YAMAMURA \\ Department of Public Health, St. Marianna University, School of Medicine, \\ Sugao, Takatsu-ku, Kawasaki, 213 Japan
}

(Received September 3, 1979)

\begin{abstract}
The outputs of inorganic arsenic compound $\left(\mathrm{As}^{+3}, \mathrm{As}^{+5}\right)$, monomethylarsonic acid (MMAA) and dimethylarsinic acid (DMAA)) in the urine were observed with passage of time after oral intake of arsenic trioxide. The subject was completely restricted from the ingestion of seafoods for two days before the experiment and during the urine sampling period, because of high arsenic content of these foods. $\mathrm{As}^{+3}$ was excreted in large amounts during the first 12 hours, the outputs corresponding to about $12 \%$ of the ingested amount, and the outputs of $\mathrm{As}^{+3}$ also were greater than those of MMAA and DMAA during the same period. The urinary outputs of arsenic compounds as total arsenic following the ingestion of arsenic trioxide amounted to $40 \%$ of the ingested amount during the first 12 hours, and $70 \%$ by 72 hours. Under restricted ingestion of seafoods, if the ratios of arsenite to total arsenic increase in the urine of arsenic workers, it is of importance as suggesting an increased absorption of toxic arsenite.
\end{abstract}

It has been shown that inorgano-arsenic compounds in the environment are metylated by microorganisms into dimethylarsinic acid, and dimethylarsinic acid is that most ubiquitous chemical form of arsenic in the biologic system. Braman and Forebeck $(1973)^{1)}$ developed a method for the isolation, separation and assay of the inorganoarsenic compounds, i.e., arsenite $\left(\mathrm{As}^{+3}\right)$ and arsenate $\left(\mathrm{As}^{+5}\right)$ and also the organo-arsenic compounds, i.e., monomethylarsonic acid (MMAA) and demethylarsinic acid (DMAA), and as a result of assay of human urine for arsenic, reported that DMAA accounted for $40-90 \%$ of the arsenic compounds in the urine. Crecelius (1977)2) also described that DMAA was excreted in the urine at the highest concentration after ingestion of $\mathrm{As}^{+3}$-rich table wine, $\mathrm{As}^{+5}$-rich well water, or organo-arsenic-rich Dungeness crab (Cancer magister).

In a previous paper $(1979)^{3}$, we described the urinary output patterns of arsenic compounds following ingestion of an arsenate-rich seaweed extract. The purpose of this study is to indicate the dynamic change of inorganic arsenic and methylarsenic compounds in human urine after oral intake as arsenic trioxide. 


\section{H. YAMAUCHI AND Y. YAMAMURA}

\section{Methods}

(1) $\mathrm{As}^{+3}$ solution ingested: $0.132 \mathrm{~g} \mathrm{As}_{2} \mathrm{O}_{3}$ (Merck AG: $99.9 \%$ purity) was dissolved in $10 \%$ solution of sodium bicarbonate, and the solution was diluted with distilled water.

(2) The subject was a 28 -year-old male weighing $70 \mathrm{~kg}$, who ingested $700 \mu \mathrm{g}$ of $\mathrm{As}^{+3}$ as the above-mentioned solution. Ingestion of marine products was completely restricted for 2 days before each experiment and also during the urine sampling period. The urine was collected during the period from 24 hours before the ingestion of the $\mathrm{As}_{2} \mathrm{O}_{3}$ solution until 72 hours after the ingestion.

(3) Separation and assay of urine $\mathrm{As}^{+3}, \mathrm{As}^{+5}, \mathrm{MMAA}$ and DMAA in the urine: To each urine sample were added $10 \%$ oxalate solution and $10 \%$ phthalate solution as buffers. Arsenic contained in the mixture was reduced into arsines with $10 \%$ sodium borohydride solution, and the arsines were then fixed with liquid nitrogen. From the fixed arsines was separated the component arsines, which were determined by arsine generation-flamless atomic absorption spectrophotometry. ${ }^{3)}$

\section{Results AND Discussion}

Fig. 1 shows changes in urinary $\mathrm{As}^{+3}, \mathrm{As}^{+5}, \mathrm{MMAA}$ and DMAA outputs following the ingestion of $\mathrm{As}^{+3}$. Ingestion of fishes and shellfishes had been restricted for 2 days before each experiments, and a 24-hour urine was assayed for the normal background

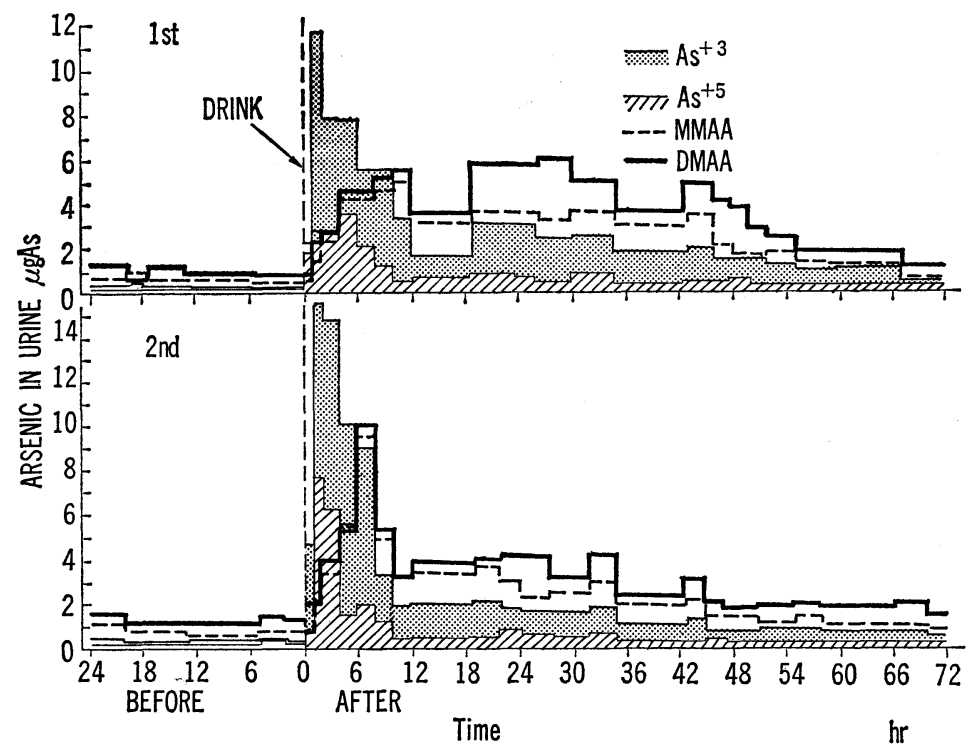

Fig. 1. Amounts of arsenic compounds in urine with time after oral intake of arsenic trioxide (10 $\mu \mathrm{g} \mathrm{As} / \mathrm{Kg})$. 


\section{INORGANIC ARSENIC AND METHYLARSENIC IN HUMAN URINE}

levels of the 4 chemical forms of arsenic. The subject then ingested $700 \mu \mathrm{g}$ of $\mathrm{As}^{+3}$, and the whole urine samples collected at 1,2, 4, 6. 8, 10 and 12 hours and then at 6hours intervals were assayed for the outputs of the 4 chemical forms of arsenic. The top half of Fig. 1 shows the results of the 1st experiment, and the bottom half, those of tbe 2 nd experiment. Table 1 shows the normal background levels of the 4 chemical

Table 1. The normal background levels of arsenic compounds in urine after restriction of seafood ingestion.

\begin{tabular}{rrrrr}
\hline $\mathrm{As}^{+3}$ & $\mathrm{As}^{+5}$ & MMAA & DMAA & Total-As \\
\hline 0.24 & 0.08 & 0.62 & 1.21 & 2.15 \\
\pm 0.07 & \pm 0.07 & \pm 0.18 & \pm 0.41 & \pm 0.70 \\
\hline
\end{tabular}

Mean \pm S.D. of 16 samples

$\mu \mathrm{g} \mathrm{As} / \mathrm{hr}$.

forms of urinary arsenic. Table 2 gives the findings by following up the 4 chemical forms [of arsenic in the urine samples collected at the aforementioned intervals for 72 hours following the oral ingestion of $700 \mu \mathrm{g}$ of $\mathrm{As}^{+3}$, which were obtained by deducting the background levels shown in Table 1 from the determined outputs.

$\mathrm{As}^{+3}$ was excreted in large amounts within the first 12 hours, and the amount of this output corresponded to about $12 \%$ of the ingested amount. Also, of the total output of $\mathrm{As}^{+3}$ during the 72-hour period, 1/3 was excreted during the first 12 hours. Furthermore, the urinary $\mathrm{As}^{+3}$ level was as low as the background level at 72 hours. The urinary outputs of MMAA and DMAA were at their peaks 6-12 hours after the ingestion of $\mathrm{As}^{+3}$, and remained at the high level until about 48 hours after the ingestion. Especially, both DMAA and MMAA remained at higher levels than $\mathrm{As}^{+3}$ at 12 hours and all the subsequent stages. $\mathrm{As}^{+5}$ increased considerably in the urine within 12 hours despite the ingestion of $\mathrm{As}^{+3}$. This increased $\mathrm{As}^{+5}$ output returned to the background level at 60 hours.

Crecelius $^{2)}$ observed four chemical forms of arsenic excreted in the urine following ingestion of $\mathrm{As}^{+3}$-rich table wine (containing $50 \mu \mathrm{g}$ of $\mathrm{As}^{+3}$ and $13 \mu \mathrm{g}$ of $\mathrm{As}^{+5}$ ), and described that $80 \%$ of the ingested amount of arsenic was excreted in the urine within 61 hours, and that, when the excreted arsenic compounds were analyzed for their chemical forms, DMAA made up 50\%; $\mathrm{As}^{+3}, 8 \% ; \mathrm{As}^{+5}, 8 \%$; and MMAA, $14 \%$ of the arsenic output. The present study differed from that by Crecelius where $\mathrm{As}^{+3}$ itself was ingested in the former, and the characteristic of this study was the output of $\mathrm{As}^{+3}$ increased markedly immediately after the ingestion.

In the next place, in order to investigate for whether there is a difference of the velocity between the urinary excretion between $\mathrm{As}^{+3}$ and $\mathrm{As}^{+5}$, the results of this study were compared with those of the previous study ${ }^{3}$ in which an $\mathrm{As}^{+5}$-rich sample was ingested (out of the subjects selected for the previous study, ${ }^{3)}$ subject B was the same 


\section{H. YAMAUCHI AND Y. YAMAMURA}

Table 2. Urinary arsenic compounds excretion following oral intake of arsenic trioxide $(10 \mu \mathrm{g} \mathrm{As} / \mathrm{Kg})$.

\begin{tabular}{|c|c|c|c|c|c|c|c|c|c|c|c|}
\hline \multirow{3}{*}{$\begin{array}{l}\text { Experiment } \\
\text { No. }\end{array}$} & \multirow{3}{*}{$\begin{array}{c}\text { Time } \\
\text { after } \\
\text { ingestion }\end{array}$} & \multicolumn{9}{|c|}{ Amounts of arsenics speies in urine } & \\
\hline & & \multicolumn{2}{|c|}{ As (III) } & \multicolumn{2}{|c|}{ As (V) } & \multicolumn{2}{|c|}{ MMAA } & \multicolumn{2}{|c|}{ DMAA } & \multicolumn{2}{|c|}{ Total-As } \\
\hline & & $\mu \mathrm{g}$ & $\% \dagger$ & $\mu \mathrm{g}$ & $\% \dagger$ & $\mu \mathrm{g}$ & $\% \dagger$ & $\mu \mathrm{g}$ & $\% \dagger$ & $\mu \mathrm{g}$ & $\% \dagger$ \\
\hline 1st & & 68.5 & 9.8 & 21.0 & 3.0 & 34.1 & 4.9 & 32.9 & 4.7 & 156.5 & 22.4 \\
\hline 2nd & $0-12$ & 95.1 & 13.6 & 29.0 & 4.1 & 47.6 & 6.8 & 45.4 & 6.5 & 217.1 & 31.0 \\
\hline$\overline{\mathbf{x}}$ & & 81.8 & 11.7 & 25.0 & 3.6 & 40.9 & 5.9 & 39.2 & 5.6 & 186.8 & 26.7 \\
\hline 1st & & 22.9 & 3.3 & 5.8 & 0.8 & 31.0 & 4.4 & 38.5 & 5.5 & 98.2 & 14.0 \\
\hline 2nd & $12-24$ & 21.0 & 3.0 & 5.0 & 0.7 & 35.2 & 5.0 & 33.1 & 4.7 & 94.3 & 13.5 \\
\hline$\overline{\mathrm{x}}$ & & 22.0 & 3.2 & 5.4 & 0.8 & 33.1 & 4.7 & 35.8 & 5.1 & 96.3 & 13.8 \\
\hline $1 \mathrm{st}$ & & 24.7 & 3.5 & 4.6 & 0.7 & 30.7 & 4.4 & 46.5 & 6.6 & 106.5 & 15.2 \\
\hline 2nd & $24-36$ & 15.8 & 2.3 & 4.9 & 0.7 & 21.3 & 3.0 & 28.9 & 4.1 & 71.0 & 10.1 \\
\hline$\overline{\mathbf{x}}$ & & 20.3 & 2.9 & 4.8 & 0.7 & 26.0 & 3.7 & 37.7 & 5.4 & 88.8 & 12.7 \\
\hline 1st & & 18.5 & 2.6 & 1.7 & 0.2 & 29.7 & 4.2 & 34.9 & 5.0 & 84.8 & 12.1 \\
\hline 2nd & $36-48$ & 8.8 & 1.3 & 2.0 & 0.3 & 14.4 & 2.1 & 14.6 & 2.1 & 42.7 & 6.1 \\
\hline$\overline{\mathbf{x}}$ & & 13.7 & 2.0 & 1.9 & 0.3 & 22.1 & 3.2 & 24.8 & 3.6 & 63.8 & 9.1 \\
\hline 1 st & & 10.1 & 1.4 & 0.9 & 0.1 & 7.3 & 1.0 & 13.8 & 2.0 & 32.1 & 4.6 \\
\hline 2nd & $48-60$ & 6.0 & 0.9 & 0.6 & 0.1 & 7.5 & 1.1 & 6.7 & 1.0 & 22.2 & 3.2 \\
\hline$\overline{\mathbf{x}}$ & & 8.1 & 1.2 & 0.8 & 0.1 & 7.4 & 1.1 & 10.3 & 1.5 & 27.2 & 3.9 \\
\hline 1st & & 5.2 & 0.7 & 0 & 0 & 2.6 & 0.4 & 3.6 & 0.5 & 11.4 & 1.6 \\
\hline 2nd & $60-72$ & 5.4 & 0.8 & 0 & 0 & 7.6 & 1.1 & 8.8 & 1.3 & 22.4 & 3.2 \\
\hline$\overline{\mathbf{x}}$ & & 5.3 & 0.8 & 0 & 0 & 5.1 & 0.8 & 6.2 & 0.9 & 16.9 & 2.4 \\
\hline \multicolumn{12}{|l|}{ Total-As } \\
\hline 1st & & 152.1 & 21.7 & 34.0 & 4.9 & 133.6 & 19.1 & 137.5 & 19.6 & 469.7 & 67.1 \\
\hline 2nd & & 149.9 & 21.4 & $41 \cdot 5$ & 5.9 & 135.4 & 19.3 & 170.2 & 24.3 & 489.5 & 69.9 \\
\hline$\overline{\mathrm{x}}$ & & 151.0 & 21.6 & 37.8 & 5.4 & 134.5 & 19.2 & 153.9 & 22.0 & 479.6 & 68.2 \\
\hline
\end{tabular}

$\dagger \%$ of dose $(700, \mathrm{~g}$ As), MMAA; Monomethylarsonic acid, DMAA; Dimethylarsinic acid

subject as in this study). The total urinary output of arsenic during the 48 hours after the ingestion of $\mathrm{As}^{+5}$ was $39 \%$ of the ingested amount, ${ }^{3)}$ while the total urinary output of arsenic ?during the first 48 hours after its ingestion in this study was $62 \%$ of the ingested amount.

This is rather contrary to the result reported by Schroeder et al ${ }^{4)}$ that $\mathrm{As}^{+5}$ was excreted more rapidly than $\mathrm{As}^{+3}$. 


\section{INORGANIC ARSENIC AND METHYLARSENIC IN HUMAN URINE}

\section{CONCLUSION}

The urinary outputs of $\mathrm{As}^{+3}, \mathrm{As}^{+5}, \mathrm{MMAA}$ and DMAA were observed during the period from 1 to 72 hours after oral ingestion of $\mathrm{As}_{2} \mathrm{O}_{3}\left(\mathrm{As}^{+3}\right)$ only once.

(1) The urinary outputs of arsenic compounds as total arsenic following the ingestion of $\mathrm{As}^{+3}$ amounted to $40 \%$ of the ingested amount within the first 12 hours, and $70 \%$ within 72 hours.

(2) When the urinary output of arsenic compounds during the 72 hours after the ingestion of $\mathrm{As}^{+3}$ was analyzed by the chemical forms of arsenic, $\mathrm{As}^{+3}$ accounted for $22 \%$; $\mathrm{As}^{+5}$, for $5 \%$; MMAA, for $19 \%$, and DMAA, $22 \%$ of the output.

(3) The output of $\mathrm{As}^{+3}$ was greater than that of MMAA and of DMAA within the first 12 hours, and corresponded to about $12 \%$ of the ingested amount of $\mathrm{As}^{+3}$.

(4) Both DMAA and MMAA in urine remained at higher levels than $\mathrm{As}^{+3}$ at all stages 12 hours or more after the ingestion of $\mathrm{As}^{+3}$, and still remained at slightly higher levels than the normal background levels even at 72 hours.

(5) Only traces of $\mathrm{As}^{+5}$ were detected, which appeared suggestive of oxidation of part of $\mathrm{As}^{+3}$ into $\mathrm{As}^{+5}$ in vivo.

The ingestion of $\mathrm{As}^{+3}$ resulted in markedly increased urinary outputs of $\mathrm{As}^{+3}$ for the following several hours. From this result, if the high ratios of arsenite to total arsenic are found in the urine of arsenic workers under restricted ingestion of seafoods, it is of importance as suggesting an increased absorption of toxic arsenite.

This study was supported in part by the Grant-in-Aid from the Japanese Ministry of Education in Scientic research (the fiscal year 1978).

\section{REFERENCES}

1) Braman, R.S. and Foreback, C.C. (1973). Science, 182, 1247.

2) Crecelius, E. A. (1977). Environ. Hlth. Perspect., 19, 147.

3) Yamauchi, H. and Yamamura, Y. (1979). Jap. J. Ind. Health, 12, 47.

4) Schroeder, H. A. and Blassa, J. J. (1966). J. Chron. Dis., 19, 85. 